\title{
A new set of tools for Ethnobiologist in the COVID-19 Pandemic
}

\author{
Ana H. Ladio ${ }^{1 *}$
}

\begin{abstract}
This article will develop a series of ideas for ethnobiologists to consider in their professional field from now on. One of the things we have most learned about indigenous communities is the importance of being committed to maintaining the networks of life and the protection of diversity. Considering the warnings given by indigenous groups regarding past and future imbalances of Nature, what will happen to ethnobiological work in the future, and is what we do really necessary? What lines of action, conflict, alliances and controversies lie ahead of us? The so-called new normality urges us to make changes in our discipline, and therefore we should be able to count on a new box of tools. In a metaphorical sense, I will call these tools a set of premises that should never be lacking in the future; we must be alert to the signs of change, the omens and the previous experiences of local communities. These pandemic times have prioritized the voices of "experts", who impose hegemonic scientific systems as if they were the only option. The critical role of indigenous peoples as guardians of the world's lands and forests should be most recognized. Indigenous peoples are neither heard nor valued, even though they are some of the worst affected by this pandemic, being subject to large-scale ethnocide at this moment. Our challenge as ethnobiologists should be to build bridges and be agents of change, so that multiculturality and interculturality can be made visible and promoted.
\end{abstract}

Keywords: COVID19; Indigenous Knowledge; Nature; Culture.

1 Grupo de Etnobiología. INIBIOMA (CONICET- Universidad Nacional del Comahue). Quintral 1250, S.C. de Bariloche, Argentina.

* Corresponding author. E-mail address: AHL (ahladio@gmail.com)

\section{SIGNIFICANCE STATEMENT}

One significant aspect of the reorientation of future ethnobiological work after Covid-19 which I would like to highlight is that we have the opportunity to draw attention to, and assign more value to, the role played by indigenous peoples in the protection and maintenance of diversity. I propose a box of tools, as a set of premises for the work in the future. This would enable us to show, more forcefully, the anomalies that exist in Nature-Culture relationships, and help to correct them from now on. 


\section{INTRODUCTION}

As pointed out by Latour (2020), this pandemic has shown us that it is quite possible for our socioeconomic system to be suspended, almost in perfect synchrony, on a global level. We now know what it feels like to slow down and put the brakes on "the progress train". So, what better moment to ask ourselves what will happen to ethnobiology in the future. Is what we do really necessary? What lines of action, conflicts, alliances and controversies lie just over the horizon?

Based on the definition of ethnobiology as a discipline that studies how human beings interact with Nature, and which involves dialogue between scientific and local knowledge systems (Ladio 2017), this article will develop a series of ideas for us to consider in our professional field from now on. Firstly, it must be emphasized that the pandemic produced by the Covid-19 virus has unleashed not only a tremendous health and economic crisis worldwide, but has also caused an upheaval that has made us rethink the meaning of life and of our relationships (Barros 2020). This is, in my opinion, a unique opportunity on a world level, and in particular for ethnobiology. It is therefore rather significant that this is exactly what the Covid-19 virus takes advantage of in order to spread - relationships between humans, and between humans and non-humans. It is evident, then, that the role ethnobiologists can play has enormous potential, not only in applied but also in theoretical terms, given that our studies are based on relationships formed between Nature and Culture.

Several ethnobiologists have begun to think about the future of ethnobiological science post Covid-19. Firstly, Gonçalves-Souza et al. (2020) point out that the warnings given by scientists as to the danger of pandemics like Covid-19 have gone unheeded up to now, and so they propose that communication between the scientific community and society must be improved, as well as scientific education within society. Volpato et al. (2020) have suggested that since the Covid-19 pandemic is a socioenvironmental problem associated with commercialization of wild resources, an integrative, interdisciplinary response is required in order to study the intensification, commoditization and exploitation of these resources by society. Franco and Bussmann (2020) have highlighted the importance of focusing our work on local communities, particularly on those with a history of interaction with zoonotic viruses. For their part, Soldati and Barros (2020) emphasize the need for a new ethnobiology, committed politically and socially, which can accompany communities through this crisis.

In Vandebroek et al. (2020), 29 ethnobiologists from different parts of the world have presented some initial ideas as to how ethnobiology should be restructured in the future. Based on the diagnosis that the Covid-19 crisis has especially impacted, and will con- tinue to impact, local, indigenous, Afro-American and migrant communities - a fact which has also been announced by the Inter-American Commission on Human Rights (IACHR, 2020) - some aspects can be identified as playing a pivotal role in our professional practice. Principally, access to wild plants and animals traditionally used by communities for subsistence will be greatly affected. The current confinement measures, plus new, post-Covid restrictions proposed by different States, will limit the use and management of these resources, for example, in local markets. The health systems of these communities will therefore be badly affected, not only because of infection with the new virus or because they will be unable to sustain their traditional health system, but also because of their general state of neglect and dispossession. For example, for over 500 years the indigenous and Afro-American peoples in America have been living in situations of extreme vulnerability, now exacerbated by the current health and economic crisis (IACHR 2020).

In addition, Vandebroek et al. (2020) have proposed that the crisis should encourage ethnobiologists to think of new ways of interacting with communities, placing emphasis on health protection, and in particular fomenting co-participation and horizontal, decolonized working methods, which many professionals lack at this time. Finally, and in accordance with Ferreira Júnior (2020), it is suggested that we should analyze new priorities for our discipline, focusing on collaborative, interdisciplinary work that is strong in theoretical and methodological terms.

One significant aspect of the reorientation of future ethnobiological work which I would particularly like to highlight is that we should consider taking this clear, revealing opportunity to draw attention to, and assign more value to, the role played by indigenous peoples in the protection and maintenance of diversity, on a global level (Rozzi 2012; Vandebroek et al. 2020).

\section{Why are indigenous peoples key to the main- tenance of diversity?}

A large and growing body of scientific literature demonstrates the critical role of indigenous peoples as guardians of the world's lands and forests. In accordance with Corrigan et al. (2018) and Garnett et al. (2018), they are better effective at protecting biodiversity than state-governed protected areas, their lands have lower rates of deforestation and forest degradation (Blackman et al. 2017), lower carbon emissions and higher carbon storage (Nolte et al. 2013). In their territories, there are more equitable and sustainable forest restoration efforts, and better social and environmental outcomes overall than in forests managed by either public or private entities (Dudley et al. 2018).

As ethnobiologists, one of the things we have most 
learned about indigenous communities is the importance of being committed to maintaining the networks of life (Toledo \& Alarcón-Cháires 2018). Since ancient times these societies have established a close, unavoidable relationship with Nature, transmitting their ethics of taking care of "Mother Earth" from generation to generation, ethics which differ from those of non-indigenous and globalized societies. What these ethics have in common is a relational framework where the different elements of Nature - such as plants, animals and humans - are perceived as equals, as coinhabitants (Zent 2014; Rozzi 2016; Vandebroek et al. 2020). From different latitudes and with different names in local languages, communities have spoken to us of good living (Escobar 2011). Thanks to the strength of movements of rural or indigenous peoples, the voices of these men and women have been advocates for the environmental ethics of their ancestors. They have also been able to adapt them to the present governance of their territories, and to the struggle implied by the process of recuperating lands that were usurped or destroyed by the capitalist model (Gorenflo et al. 2012; Escobar, 2016).

However, one of the most surprising aspects is that these peoples have warned us that this crisis was going to happen. Just like the environmental scientists or climate change specialists whose words have not been heeded, for a long time several indigenous representatives have been declaring that the relational models established with Nature on the part of global societies are profoundly destructive (Indigenous and Community Response 2019). From their perspective, the main cause of this imbalance has been the imposition of unscrupulous global market logic based on indiscriminate destruction of woods, rivers, plains and forests. The fight against the expansion of polluting industrial agriculture, mega-mining and exploitation of hydrocarbon resources has been one of their main battles (Escobar 2016).

Indigenous women leaders have particularly warned about the loss of values associated with the networks of life. They have been able to promote discussion of the idea that the extractivist domination of $\mathrm{Na}$ ture proposed by capitalist market logic is comparable to that imposed on the bodies of women over centuries of colonization (Siliprandi 2010; Klier and Núñez 2019). These territories-bodies are therefore subject to strong forces of destruction, inequality and repression, all serving the objective of economic gain.

Many signs of change have been perceived from detailed reading of the climate and the behavior or abundance of animals and plants (Castillo and Ladio 2017, 2020). As shown in Ibacache Burgos et al. (2002), the great horned owl (Buho virginianus) was lost due to the felling of native forests, and losing the owl meant that illness could not be foretold, so there was no way to prevent it. Astrological phenomena or volcanic activity have also been indicated as harbingers of long-term change or omens of future times of destruction, illness and hunger (Calvo 1994). In various testimonies referring to ceremonies carried out by indigenous peoples, such as healing rituals, one of the repeated messages is that societies, mainly non-indigenous ones, have continually transgressed against Nature - cutting down forests, contaminating rivers and oceans, and carrying out devastating extractive exploitation of natural resources (Ibacache Burgos et al. 2002). From their vision of Nature as a living entity, the different beings that live on the land - in the case of the Mapuche communities, the ngen (the owners, in Mapudungun language) - are perceived as being angry and sad, and to be preparing a counter attack to teach a lesson to those who have dared to interfere in, violate, and destroy the environment (Moyano 2020). A testimony of Orlando Carriqueo, werken (spokesperson in Mapudungun language) of Río Negro Mapuche-Tehuelche Parliament (2020), clearly explains his vision: "Humanity should not look for anyone to blame specifically, but rather begin to assume responsibility collectively, as a society. Bats are not to blame [for Covid 19] nor are the Chinese who ate the bats. What is happening has much more to do with a context in which lands have been ravaged, where this bat has been displaced from its natural habitat, where the water, air and soil are all contaminated. We have had previous experiences like this, with swine and avian influenza. Therefore, we have to start looking for the cause in all the imbalance we have provoked as humanity, as society, in the different territories; that is the price we are paying now.". Even if governments cooperate with each other and buy millions of artificial respirators, if we don't change our lifestyles, we will suffer this again in a short time".

\section{A new phase of ethnobiology}

Considering the warnings given by indigenous groups regarding past and future imbalances, what will happen to ethnobiological work in the future, and is what we do really necessary? What lines of action, conflict, alliances and controversies lie ahead of us? One of the great merits of ethnobiology is that it exposes the fact that there is no single way of perceiving Nature, managing it or protecting it (Toledo and AlarcónCháires 2018). It has been demonstrated empirically that market society overexploitation and domination is not the only model that exists - there are alternatives, which can be seen in traditional societies (Graziano Ceddia et al. 2015); cultural homogeneity does not exist, the bonds we form with plants and animals and other beings are unique and multidimensional, societyperson-species. For this reason I think that our discipline is still necessary, although perhaps I would give 
it a humbler name than the science of survival (Prance 2007), since the movements of indigenous peoples, local communities, immigrants and Afro-Americans do not depend on us for their survival. In these new times, they are going about their business, strengthening their voice with self-determination and autonomy; we will simply accompany them in their struggles, and will doubtless be faithful promotors of their wisdom.

The so-called new normality urges us to make changes in our discipline, and therefore we should be able to count on a new box of tools. In a metaphorical sense, I will call these tools a set of premises that should never be lacking in the future; we must be alert to the signs of change, the omens and the previous experiences of local communities. The tools involve theoretical-epistemological positioning, but also deal with issues that have arisen from our current circumstances, the pandemic:

\section{Tool 1. Immateriality}

Ethnobiological study of the immateriality of our biocultural heritage is key to counteracting materialistic views of Nature, which are in some way the cause of its overexploitation and imbalance. Ethnobiological studies have highlighted the need to consider both tangible and intangible aspects (Maffi 2005). Biocultural heritage does not refer merely to a set of plant varieties, animal races, wild species and areas, systems and landscapes which were intentionally created, maintained and used by cultural groups, it also refers to epistemic and linguistic dimensions; that is, the beliefs, rituals, traditions, art, rules of land use, and the knowledge and innovation developed over time and transmitted by both men and women (Toledo \& Alarcón-Cháires 2018). These guidelines and rules, often reflected in myths and legends, constitute the vehicle that ensures the maintenance of biodiversity (Aillapan and Rozzi 2004; Garibaldi and Turner 2004; Kushwah et al. 2017). The relationships that show immateriality are those we should make even more visible in our ethnobiological research, together with empirical environmental evidence.

\section{Tool 2. Biocultural Epidemiology}

A biocultural and intercultural epidemiological approach is necessary, which can show us more faithfully how people and their health form part of multiple networks of biological and sociocultural conditioning factors. The Covid-19 pandemic has revealed the role of connectivity on a global level, through transport networks, which permitted rapid, extensive invasion of the virus (Nuñez et al. 2020). However, it has also exposed sociocultural inequalities, generating perverse situations, such as the fact that the elderly and socioenvironmentally vulnerable have suffered the high- est mortality rates, both in urban and rural areas. High population density and the lack of adequate urban infrastructure has also aggravated the situation, increasing the likelihood of contracting the virus.

The pandemic has exposed the socioenvironmental fragility of urban life, the lack of food and health autonomy, and individuals who are ignorant of how to cultivate their own food and medicine. In addition, the spatial organization of a city does not offer sufficient health barriers, due to the low number of green spaces, the little distance between dwellings, crowded living conditions, and overcrowded public transport, for example. In this sense, indigenous peoples, migrants and Afro-Americans who inhabit cities are the hardest hit, for the reasons mentioned above, added to work conditions which generally violate human rights (Del Popolo et al. 2007). At present, the population of indigenous peoples lives mainly in cities, not in rural areas; for example, in Argentina $80 \%$ of the indigenous population inhabits urban centers (INDEC 2015).

Most particularly, this pandemic reveals the need for epidemiology which is intercultural, pluralistic and comprehensive, includes a spiritual dimension, and recognizes history and its different ways of understanding health and illness, as well as its biophysical determinants. Our work should be able to consider these epidemiological aspects as fundamental components in our understanding of the differential strategies and difficulties experienced by city dwellers, compared to those living in rural areas. We should especially emphasize and draw attention to changes in the relationships with Nature and the triggering factors. This would enable us to show, more forcefully, the anomalies that exist in Nature-Culture relationships, and help to correct them for the future.

\section{Tool 3. Biocultural perception of risk}

If the warnings that came from indigenous communities went unheeded, as did the risk analyses of scientists, we should focus on determining what the understanding of risk is in global societies. Why have urban societies felt distanced from the disturbances of Nature? Nuñez et al. (2020) have recently indicated that proliferation of a new organism, such as the Covid-19 virus, which inhabits a host (human being) that is different from its original host (bat?, pangolin?), and spreads rapidly thanks to its ability to adapt, can be seen as a particular case of biological invasion, although it doubtless has greater direct consequences for human health than the invasion of a plant or animal. Studies in indigenous communities have been able to show the perception of risk of biological invasions, and their interpretation as socioenvironmental phenomena whose social and biological components are inseparable. This is the case of the invasion of exotic trout 
(Oncorhynchus mykiss and Salvelinus fontinalis) in the rivers and lakes of Patagonia, where they displace native fish species, or of the pines (Pino radiata) and eucalyptus trees (Eucalipto globulus) that affect the natural regeneration of native forests (Bravo-Vargas et al. 2018). Since their arrival in the 20th century, these invasive species have been experienced by the Mapuche communities as signs of the winka (white man in Mapudungun language), as an omen that something bad will happen in the family (Aigo and Ladio, 2016). The Covid-19 pandemic is currently experienced in the same way, as vñfitun, which means to damage, to infect, to have detrimental effects; the noun is vinfi, and this forms the word koronavñfi, or coronavirus, a neologism in Mapudungun to name the pandemic (Loncon 2020). This illness is perceived in the same way as so many others that have decimated their populations in times of conquest, such as measles, smallpox and typhus, etc. All were brought by the white man and have been the cause of spiritual and material imbalance for individuals, communities and the Mapuche territory.

The strategy of these peoples has been avoidance, isolation, supportive community life and selfsufficiency, together with a continuous struggle against the exploitation models mentioned, which have undermined their wellbeing. The philosophical equivalence they assign to the illnesses and biological invasions brought to them from afar by the conquering, market society should not be underestimated. It is significant in terms of intercultural analysis of the historical and current contexts of the spread of these disturbances. In this sense, studies focusing on the perception of risk and the adaptive strategies carried out by different cultures from an ethnobiological perspective will be essential (Estévez et al. 2015, Atallah 2016; Magalhães et al. 2019).

\section{Tool 4. Ecofeminism}

Finally, although there may seem to be no connection, ethnobiology should include more ecofeminist theory in its post Covid-19 investigations (Ladio 2020). This is because the environmental exploitation that has brought about this pandemic and other imbalances of Nature is a patriarchal problem, given that it implies the subjection of territories, in the same way as women's bodies are subjected (Puleo 2015). The relationships of overexploitation or domination of Nature which are common in a market society can only be deactivated if emphasis is placed on the search for models of environmental care, where men and women take equal responsibility for sustaining the networks of life, as proposed by ecofeminism. It is not only the duty of females or males, or of non-gender human beings; the responsibility lies with everyone equally, with their differences and complexities. The next ethnobiologi- cal studies should therefore deal particularly with the gender quandaries in Nature conservation. We have to become aware of the prevailing gender hierarchies in natural resource commoditization, the invisibilization of restoration activities, mainly carried out by women, and the important role played by women in healthy eating, and we must give a voice to rural leaders who face up to the large extractive companies, just to mention some of the actions that are essential when faced with homogenizing premises.

\section{CONCLUSION}

Ethnobiology as a contextual, dynamic science should not be oblivious to the changes experienced due to this pandemic. The critical role of indigenous peoples as guardians of the world's lands and forests should be most recognized. The voices of diverse indigenous peoples have strongly asserted that the first line of battle against this pandemic will be found in the community, in social organization, and in local ecological knowledge of the care and isolation needed to prevent infection. It also depends on care of the environment, on listening to "Mother Earth", on the sowing and storage of seeds, on spiritual nourishment, on solidarity and empathy. Nevertheless, these times have prioritized the voices of "experts", who impose hegemonic scientific systems as if they were the only option. Indigenous peoples are neither heard nor valued, even though they are some of the worst affected by this pandemic, being subject to large-scale ethnocide at this moment. Our challenge as ethnobiologists should be to build bridges and be agents of change, so that multiculturality and interculturality can be made visible and promoted, aspects which will be crucial as we ask ourselves what we want our future relationships to be like, and how the criteria of individual and collective wellbeing will be determined in our world.

\section{ACKNOWLEDGEMENT}

The author acknowledges valuable comments from Ulysses Paulino Albuquerque on this paper. The author acknowledges CONICET and Universidad Nacional del Comahue.

\section{CONFLICT OF INTEREST}

The author has no conflicts of interest to declare. 


\section{REFERENCES}

Aigo, J, Ladio A (2016) Traditional Mapuche ecological knowledge in Patagonia, Argentina: Fishes and other living beings inhabiting continental waters, as a reflection of frocesses of change. Journal of Ethnobiology and Ethnomedicine 12:56. doi: https://doi.org/10.1186/ s13002-016-0130-y

Aillapan L, Rozzi R (2004) Una etno-ornitología Mapuche contemporánea: veinte poemas alados de los bosques nativos de Chile. Ornitología Neotropical 15:1-16.

Atallah DG (2016) Toward a decolonial turn in resilience thinking in disasters: Example of the Mapuche from Southern Chile on the frontlines and faultlines. International Journal of Disaster Risk Reduction 19:92-100. doi: https://doi. org/10.1016/j.ijdrr.2016.08.027

Barros FB (2020) Sobre dor, sofrimento e esperança: $O$ novo Coronavírus e a condição humana no Antropoceno. Ethnoscientia 5 doi:ethnoscientia.v5i1.290

Bravo-Vargas, VR García A,Pizarro JC, Pauchard A (2018) Do people care about Pine invasions? Visitor perceptions and willingness to pay for Pine control in a protected area. Journal of Environmental Management. doi: https://doi.org/10. 1016/ J . JENVMAN . 2018.07.018

Blackman A, Corral L, Santos Lima S, Asner GP (2017) Titling indigenous communities protects forests in the Peruvian Amazon. PNAS April 18, 2017114 (16) 4123-4128. doi: https://doi.org/10. $1073 /$ pnas . 1603290114

Calvo M (1994) Secretos y Tradiciones Mapuches. Andres Bello, Santiago de Chile, Chile.

Castillo L, Ladio A (2017) Mammals and birds as ethno-indicators of change: Their importance to livestock farmers in Arid Patagonia (Argentina). Environment, Development and Sustainability. doi: https://doi.org/10.1007/ s10668-017-9983-z

Castillo L, Ladio A (2020) Ethnoindicators of environmental change: local knowledge use for rangeland management among smallholders of Patagonia. Rangeland Ecology \& Management. doi: https://doi.org/10.1016/j.rama.2020.06.001

Corrigan C, Bingham H, Shi, Y., Lewis, E, Chauvenet, A, Kingston N (2018) Quantifying the contribution to biodiversity conservation of protected areas governed by indigenous peoples and local communities. Biological Conservation, 227, 403-4212. doi: https ://doi.org/10.1016/j.biocon.2018.09. 007

Del Popolo F, Oyarce AM,Ribotta B, Rodríguez Vignoli J (2007) Indigenous peoples and urban settlements: spatial distribution, internal migration and living conditions. CEPAL. Serie Población y Desarrollo 78:0-82.

Dudley N, Jonas H, Nelson F, Parrish J, Pyhälä A, Stolton S, Watson EMJ (2018) The essential role of other effective area-based conservation measures in achieving big bold conservation targets. Global ecology and conservation 15 4-24. doi: https://doi.org/10.1016/j.gecco.2018.e00424

Escobar A (2011) Una minga para el posdesarrollo. Signo y Pensamiento 58-Punto de Vista XXX:306-312.

Escobar A (2016) Sentipensar con la Tierra: Las luchas territoriales y la dimensión ontológica de las epistemologías del sur. AIBR, Revista de Antropología Iberoamericana 11:11-32. doi: https: //doi.org/10.11156/aibr.110102

Estévez RA, Anderson CB, Pizarro JC, Burgman MA (2015) Clarifying values, risk perceptions, and attitudes to resolve or avoid social conflicts in invasive species management. Conservation $\mathrm{Bi}-$ ology 29(1):19-30. doi: https://doi.org/10.1111/ cobi. 12359

Franco, M, Bussmann RW (2020) Rising to the Occasion: Outlining Ethnobiologists' response to the Coronavirus (COVID-19) Pandemic. Ethnobotany Research and Applications 20:1-4. http://www . ethnobotanyjournal .org/ index.php/era/article/view/2135. doi: http:// dx.doi.org/10.32859/era.20.06.1-4

Ferreira Júnior WS (2020) Reflections on the Theoretical Advance in Ethnobiology: are we pointing to the Wrong direction? Ethnobiology and Conservation 9. https://ethnobioconservation. com/index.php/ebc/article/view/411. doi: https://doi.org/10.15451/ec2020-05-9.20-1-8.

Garibaldi A, Turner N (2004) Cultural keystone Species: Implications for ecological conservation and restoration. Ecology and Society 9. http://www.ecologyandsociety.org/vol9/ iss $3 / \operatorname{art} 1 \%$ AInsight

Garnett, ST, Burgess ND, Fa JE, FernándezLlamazares A, Molnár Z, Robinson CJ, Watson JEM, Zander KK, Austin B, Brondizio EB, Collier NF, Duncan R, Ellis W, Geyle H, Jackson MV, Jonas H, Malmer P, McGowan B, Sivongxay A, Leiper I (2018) A spatial overview of the global importance of In- 
digenous lands for conservation. Nature Sustainability 1, 369-374. doi: https://doi.org/10.1038/ s41893-018-0100-6

Gonçalves Souza T, Filho JAFD, Albuquerque UP (2020) Why scientific information does not necessarily impact the decisions by human society. Ethnobiology and Conservation 9. https://ethnobioconservation.com/index. php/ebc/article/view/387 doi: https://doi.org/ 10.15451/ec2020-05-9.11-1-5.

Gorenflo, LJ, Romaine S, Mittermeier RA, WalkerPainemilla K (2012) Co-occurrence of linguistic and biological diversity in biodiversity hotspots and high biodiversity wilderness areas. Proceedings of the National Academy of Sciences of the United States of America 109 (21): 8032-8037.

Graziano Ceddia M, Gunter U, Corriveau-Bourque A (2015) Land tenure and agricultural expansion in Latin America: The role of Indigenous Peoples' and local communities' forest rights. Global Environmental Change 35: 316-322.

IACHR.2020. Inter-American Commission on Human Rights. Accessed 27 june 2020

Ibacache Burgos J, McFall S,Quidel J (2002) Rume Kagenmew Ta Az Mapu, Epidemiologia de la Trasgresión en Makewe-Pelale. Working Paper Series 2 Ñuke Mapuförlaget, Santiago de Chile, Chile.

INDEC (2015) Censo Nacional de Población, Hogares y Viviendas 2010: Censo del Bicentenario. Pueblos originarios: región Patagonia. Serie D. Número 2. Instituto Nacional de Estadística y Censos, Buenos Aires, Argentina.

Indigenous and Community Response (2019) A statement on the IPCC special report on climate change and land from indigenous peoples and local communities from 42 countries spanning $\mathbf{7 6 \%}$ of the world's tropical forests. https:// ipccresponse.org/home-en Accessed 27 june 2020.

Klier G, Núñez PG (2019) Verde Que Te Quiero Verde: Una Mirada Feminista Para La Conservación de La Biodiversidad. Intropica 14. doi: https://doi.org/10.21676/23897864.3252

Kushwah VS, Sisodia R, Bhatnagar C (2017) Magicreligious and social belief of tribals of district Udaipur, Rajasthan. Journal of Ethnobiology and Ethnomedicine 13:1-7. doi: https://doi.org/10. 1186/s13002-017-0195-2

Ladio A (2017) Ethnobiology and Research on Global Environmental Change: What Distinctive Contribution Can We Make? Ethnobiology and Conservation 6. https: //ethnobioconservation.com/index.php/ebc/ article/view/116 doi: https://doi.org/10. $15451 /$ ec2017-07-6.7-1-8

Ladio A (2020) Etnobiología en áreas rurales y su aporte a la lucha para desentrañar sesgos patriarcales. Ethnosciencia 5. http://ethnoscientia. com/index.php/revista/article/view/298 doi: https://doi.org/10.22276/ethnoscientia.v5i1. 298 ethnoscientia.v5i1.298

Latour B (2020) ¿Qué Medidas de protección para evitar el regreso del modelo de producción de la pre-crisis? Encarcelamiento masivo. Derecho, Raza y Castigo:143-234. doi: https://doi.org/10.2307/ j.ctvwcjdp1.5

Loncon E (2020) Entrevista. Accessed 27 june 2020.

Maffi L (2005) Linguistic, cultural, and biological Diversity. Annual Review of Anthropology 34:599-617. doi: https://doi.org/10.1146/ annurev . anthro.34.081804.120437

Magalhães HF, Silva Oliveira RC, Feitosa IS, Albuquerque UP (2019) Collection and Analysis of Environmental Risk Perception Data. In: Albuquerque UP, Lucena R, Cruz da Cunha, Alves R. (eds) Methods and Techniques in Ethnobiology and Ethnoecology. Springer Protocols Handbooks. Humana Press, New York, USA, pp. 149-163

Moyano A (2020) Para el pensamiento mapuche, el Covid19 es una resultante antes que un fenómeno en sí mismo. Accessed 27 june 2020

Nolte C, Agrawal A, Silvius KM, Soares-Filho BS (2013) Governance regime and location influence avoided deforestation success of protected areas in the Brazilian Amazon. PNAS March 26, 2013 110 (13) 4956-4961. doi: https://doi.org/10.1073/ pnas. 1214786110

Nuñez, MA, Pauchard A, Ricciardi A (2020) Invasion science and the global spread of SARS-CoV2. Trends in Ecology and Evolution. doi: https: //doi.org/10.1016/j.tree.2020.05.004

Parlamento Mapuche-Tehuelche de Río Negro (2020) Accessed 27 june 2020

Prance, GT. (2007) Ethnobotany, the science of survival: A declaration from Kaua'i. Economic Botany doi: 10.1007/BF02862367

Puleo AH (2015) Ecología y Género En Diálogo Interdisciplinar. Plaza y Vades Editores, Madrid, España

Rozzi R (2012) Filosofía Ambiental Sudamericana: Raíces Amerindias Ancestrales y Ra- 
mas Académicas Emergentes. Environmental Ethics 34:9-32. doi: https://doi.org/10.5840/ enviroethics201234Supplement52.

Rozzi R (2016) Bioética global y ética Biocultural. Cuadernos de Bioética 27:339-355.

Siliprandi E (2010) Mujeres y agroecología. Nuevos sujetos políticos en la agricultura familiar. Investigaciones Feministas 1:125-137 doi: https: //dx.doi.org/10.5209/INFE

Soldati GT, Barros FB (2020) The COVID19 Pandemic and future of ethnobiology. Ethnobiology and Conservation 9. https: //ethnobioconservation.com/index.php/ebc/ article/view/405 doi: https://doi.org/10. 15451/ec2020-05-9.17-1-4

Toledo V, Alarcón-Cháires P (2018) Tópicos Bioculturales. Reflexiones Sobre El Concepto de Bioculturalidad y La Defensa Del Patrimonio Biocultural de México. Universidad Autónoma de México, Morelia, México.

Vandebroek I, Pieroni A, Stepp JR, Hanazaki N, Ladio A, Alves RRN, Picking D, Delgoda R, Maroyi A, Van Andel T, Quave CL, Paniagua-Zambrana NY, Bussmann RW, Odonne G, Abbasi AM, Albuquerque
UP, Baker J, Kutz S, Timsina S, Shigeta M, Pereira T, Oliveira R, Hurrell JA, Arenas PA, Puentes J,. Hugé J, Yeşil Y, Pierre LJ, Olango TM (2020) Reshaping the future of ethnobiology research after the COVID-19 Pandemic. Nature Plants doi: https://doi.org/10.1038/s41477-020-0691-6

Volpato G, Fontefrancesco MF, Gruppuso P, Zocchi DM, Pieroni A (2020) Baby Pangolins on my plate: possible lessons to learn from the COVID19 Pandemic. Journal of Ethnobiology and Ethnomedicine 16:1-12. doi: https : //doi .org/10.1186/ s13002-020-00366-4

Zent E (2014) Ecogonía III. jkyo ecogonía iii. jkyo jkwainï: la filosofía jkwainï: La filosofía del cuidado de la del cuidado de la vida de los Jotï del Amazonas Venezolano. Etnoecológica 10:101121

Received: 28 June 2020

Accepted: 29 June 2020

Published: 07 July 2020 